sen, J. Nienhuis and E.W. Triplett. 1996. Molecular microbial diversity of an agricultural soil in Wisconsin. Appl. Environ. Microbiol. 62:1943-1945.

3.Borriello, F. and K.S. Krauter. 1990. Reactive site polymorphism in the murine protease inhibitor gene family is delineated using modification of the PCR reaction $(\mathrm{PCR}+1)$. Nucleic Acids Res. 18:5481-5487.

4.Gussow, D. and T. Clackson. 1989. Direct clone characterization from plaque and colonies by the polymerase chain reaction. $\mathrm{Nu}$ cleic Acids Res. 17:4000.

5.Jensen, M.A. and N. Straus. 1993. Effect of PCR conditions on the formation of heteroduplex and single-stranded DNA products in the amplification of bacterial ribosomal DNA spacer regions. PCR Methods Appl. 3:186-194.

6.Moré, M.I., J.B. Herrick, M.C. Silva, W.C. Ghiorse and E.L. Madsen. 1994. Quantitative cell lysis of indigenous microorganisms and rapid extraction of microbial DNA from sediment. Appl. Environ. Microbiol. 60:15721580.

7.Parkinson, J.M., J.R.G. Pöhler and D.M.J. Lilley. 1998. Catalytic and binding mutants of the junction-resolving enzyme endonuclease I of bacteriophage T7: role of acidic residues. Nucleic Acids Res. 27:682-689.

8.Sambrook, J., E.F. Fritsch and T. Maniatis. 1989. Molecular Cloning: A Laboratory Manual, 2nd ed., p. 1.86 and E.12. CSH Laboratory Press, Cold Spring Harbor, NY.

9.Smit, E., P. Leeflang, B. Glandorf, J. Dirk van Elsas and K. Wernars. 1999. Analysis of fungal diversity in the wheat rhizosphere by sequencing of cloned PCR amplified genes encoding 18S rRNA and temperature gradient gel electrophoresis. Appl. Environ. Microbiol. 65: 2614-2621.

10.Torsvik, V.L., J. Goksøyr and F.L. Daae. 1990. High diversity in DNA of soil bacteria. Appl. Environ. Microbiol. 56:782-787.

11.Vitousek, P.M., J.D. Aber, R.W. Howarth, G.E. Likens, P.A. Matson, D.W. Schindler, W.H. Schlesinger and D. Tilman. 1997. Human alteration of the global nitrogen cycle: causes and consequences. Issues in Ecology, Spring. Ecological Society of America, Washington, D.C. 1:1-15.

12.Wenger, R.H. and P.J. Nielsen. 1991. Reannealing of artificial heteroduplexes generated during PCR-mediated genetic isotyping. Trends Genet. 7:178.

13.White, T.J., T. Bruns, S. Lee and J. Taylor. 1990. Amplification and direct sequencing of fungal ribosomal RNA genes for phylogenetics, p. 314-322. In M.A. Innis, D.H.Gelfand, and J.J. Sninsky (Eds.), PCR protocols: A Guide to Methods and Applications. Academic Press, San Diego, CA.

14.Wintzingerode, F.V., U.B. Göbel and E. Stackebrandt. 1997. Determinations of microbial diversity in environmental samples: pitfalls of PCR-based rRNA analysis. FEMS Microbiol. Rev. 21:213-229.

Support for this study was provided by the USDA-NRICGP under project no. 9735101-4317. The enzyme and control plasmid DNA used in this study were graciously donated by New England Biolabs, Beverly, MA, USA. Advice on the use of T7 endonuclease I was received from X.Y. Qiu of Oak Ridge National Laboratories in Oak Ridge, TN, USA. Support and advice from Catherine Lozupone and Greg Sturbaum were deeply appreciated. Address correspondence to Jennifer L. Lowell, Department of Microbiology, Colorado State University, Fort Collins, CO 80523-1677, USA. Internet: jlowell@cvmbs.colostate.edu

Received 20 August 1999; accepted 7 January 2000.

Jennifer L. Lowell and Donald A. Klein Colorado State University Fort Collins, CO, USA

\section{Relative Quantitative RT-PCR Protocol for TrkB Expression in Neuroblastoma Using $G A P D$ as an Internal Control}

BioTechniques 28:681-691 (April 2000)

\section{ABSTRACT}

An RT-PCR protocol for the relative quantitative measurement of TrkB transcripts using glyceraldehyde-3-phosphatedehydrogenase (GAPD) transcripts as an internal control is described. Both TrkB and GAPD sequences were co-amplified in the exponential phase of amplification using 5 '-biotinylated primers. The PCR products were subjected to PAGE, electro-transferred to nylon membrane and detected by a chemiluminescent procedure using alkaline phosphatase conjugated with avidin. Signals detected on $X$-ray film were analyzed by densitometry. The ratio between TrkB and GAPD expression levels was determined to normalize the expression levels of TrkB transcripts. Initially, strong signals of GAPD transcripts led to overexposure of $X$ ray film compared to those of $\mathrm{TrkB}$, which 


\section{Short Technical Reports}

causes difficulties in the accurate determination of the TrkB/GAPD ratio. To circumvent this problem, uniformly biotinylated GAPD primers were replaced with a mixture of biotinylated and non-biotinylated GAPD primers of the same sequence and concentration. GAPD signals detected on $X$-ray film were proportionally decreased as the amount of biotin-labeled primers was reduced in the total GAPD primers. This modification enabled both GAPD and TrkB signals to be analyzed within the linear range of $X$-ray film detection without affecting the amplification efficiency of TrkB sequence. Use of composite primers may have a wide range of applicability in quantitative analysis of nucleic acids.

\section{INTRODUCTION}

PCR is a well-established technique for the rapid amplification of specific DNA sequences in vitro. Amplification of RNA can also be achieved by a combination of reverse transcription (RT) and subsequent PCR. RT-PCR $(1,8)$ is more sensitive than traditional RNA analysis techniques such as Northern blot analysis (11) and is able to detect rare RNA species and transcripts from small numbers of cells or small amounts of tissues. However, quantitative analysis by RT-PCR can be difficult because of the exponential nature of PCR. A small variation during the assay might yield a marked change in the amount of the final product (2). The use of internal standards is therefore desirable in quantitative RT-PCR analysis to correct variations in RT, PCR as well as product detection steps (3). An ideal endogenous standard would be a transcript in which the expression is constant during the cell cycle, between cell types or in response to external stimuli. A housekeeping gene GAPD that is transcribed constitutively in most cell types and tissues has been commonly used as an invariant control. Previous studies on Trk expression in neuroblastoma cell lines and tumors showed that $G A P D$ was a suitable control $(9,13)$.

To analyze PCR products, agarose or polyacrylamide gel electrophoresis is commonly used. PCR products separated on gels are visualized by ethidium bromide staining. More sensitive detection of PCR products is achieved by use of blotting-based techniques in which the PCR products are first transferred to a membrane and are detected by hybridization with radioactively labeled probes. Alternatively, 5'-biotinylated primers are used to label PCR products, and the biotinylated PCR products are detected by chemiluminescence using horseradish peroxidase or alkaline phosphatase conjugated with avidin (4). In addition, 5'-fluorophor-labeled primers can also be used for the detection of small amounts of PCR products. A sensitive detection of PCR products is essential for quantitative RT-PCR analysis because PCR has to be performed at a reduced number of cycles to ensure that the amplification is in the exponential phase. Under these conditions, the amount of PCR products generated is too small to be detectable by dye staining.

We describe here a method for relative quantification of RNA expression by RT-PCR. This protocol addresses one of the common problems in the relative quantitative RT-PCR: the difference between expression levels of targets and internal controls. Using composite primers (a mixture of 5'-labeled and nonlabeled primers of the same sequence and concentration), we were able to modulate the apparent signal intensity of internal control detected on X-ray film. As a result, both signals of the gene of interest and internal control can be analyzed within the linear range of $\mathrm{X}$ ray film detection. We also showed that the use of composite primers in relative quantitative PCR did not compromise the principle of the assay. Furthermore, the use of composite primers may have a wide range of applicability in the quantitative analysis of nucleic acids.

\section{MATERIALS AND METHODS}

\section{Cell lines}

All cell lines used in the study were from the collection of the cell bank at the Children's Hospital of Philadelphia.

\section{Isolation of RNA}

Total cellular RNA was extracted from neuroblastoma cell lines using the Totally $\mathrm{RNA}^{\mathrm{TM}}$ kit (Ambion, Austin,
TX, USA) according to the manufacturer's instructions. The concentration of RNA in these samples was determined by optical density (OD) of the samples at $260 \mathrm{~nm}$ and converting it to the RNA concentration using the cofactor of $1 \mathrm{OD}=40 \mu \mathrm{g} / \mathrm{mL}$.

\section{First-Strand cDNA Synthesis}

The RT reaction was carried out using $2.5 \mu \mathrm{g}$ of total RNA in a total volume of $20 \mu \mathrm{L}$ containing $150 \mathrm{ng}$ random hexamers (Life Technologies, Gaithersburg, MD, USA), $0.5 \mathrm{mM}$ dNTPs, $10 \mathrm{mM}$ dithiothreitol, $200 \mathrm{U}$ SUPERSCRIPT ${ }^{\mathrm{TM}}$ II reverse transcriptase (Life Technologies) in the reaction buffer consisting of $20 \mathrm{mM}$ Tris- $\mathrm{HCl}$ (pH 8.4), $50 \mathrm{mM} \mathrm{KCl,} 2.5 \mathrm{mM} \mathrm{MgCl}{ }_{2}$. Initially, the total RNA was denatured at $70^{\circ} \mathrm{C}$ for $10 \mathrm{~min}$ and immediately chilled on ice. First-strand cDNA was obtained after $10 \mathrm{~min}$ at $23^{\circ} \mathrm{C}$ and 50 min at $42^{\circ} \mathrm{C}$, followed by $70^{\circ} \mathrm{C}$ for 15 min. Two units of RNase H (Life Technologies) were then added to each reaction, and the resultant mixture was further incubated at $37^{\circ} \mathrm{C}$ for $20 \mathrm{~min}$.

\section{PCR}

PCR was carried out in a final volume of $10 \mu \mathrm{L}$, containing $0.5 \mathrm{U}$ of Taq Gold $^{\circledR}$ DNA polymerase (PE Biosystems, Foster City, CA, USA), $200 \mu \mathrm{M}$ dNTPs, $0.4 \mu \mathrm{M}$ of each primer, in a buffer consisting of $50 \mathrm{mM} \mathrm{KCl}, 10$ $\mathrm{mM}$ Tris- $\mathrm{HCl}$ (pH 8.3), $2.0 \mathrm{mM} \mathrm{MgCl} 2$ and $1 \mu \mathrm{L}$ of the RT product (reversetranscribed total RNA). The 5' biotin-labeled primers used for the amplification of a $\operatorname{TrkB}$ were 5'-GCAATG- ATGATGACTCTGCC-3' (sense) and 5'-GGAACACTTTTCCAAAGGCT-3' (antisense). The $5^{\prime}$ biotin-labeled and nonlabeled primers used for the amplification of GAPD were 5'-CATCAAGAAGGTGGTGAAGC-3' (sense) and 5'-GAGCTTGACAAAGTGGTCGT-3' (antisense). GAPD primers were added together with $T r k B$ primers in the same PCR. All samples were overlayed with mineral oil. Amplification was performed on a PTC- $100^{\mathrm{TM}}$ programmable thermal controller (MJ Research, Watertown, MA, USA). The samples were first denatured at $95^{\circ} \mathrm{C}$ for $12 \mathrm{~min}$, followed by $5,10,15$ or 20 cycles of $95^{\circ} \mathrm{C}$ 


\section{Short Technical Reports}

for $30 \mathrm{~s}, 55^{\circ} \mathrm{C}$ for $30 \mathrm{~s}$ and $72^{\circ} \mathrm{C}$ for 90 $\mathrm{s}$. The final cycle was followed by a 5 min extension step at $72^{\circ} \mathrm{C}$ to ensure that the amplified DNA was doublestranded. The absence of cellular DNA contaminants was routinely checked by RT-PCR assays of negative control samples (no RT had been added). The following compositions of GAPD primers were used: (i) GAPD 1: $100 \%$ biotiny- lated, (ii) GAPD 1:24: 4\% biotinylated primers $+96 \%$ nonbiotinylated primers, (iii) GAPD 1:49: $2 \%$ biotinylated primers $+98 \%$ nonbiotinylated primers and (iv) GAPD 1:99: 1\% biotinylated primers $+99 \%$ nonbiotinylated primers.

\section{Detection of PCR Products}

PCR products $(10 \mu \mathrm{L})$ were subject- ed to non-denaturing 6\% PAGE (75 min, $90 \mathrm{~V})$ in TBE buffer ( $89 \mathrm{mM}$ Tris base, $89 \mathrm{mM}$ boric acid, $2 \mathrm{mM}$ EDTA, $\mathrm{pH}$ 8.3). DNA bands were electro-transferred onto nylon membrane (Hybond ${ }^{\circledR}$ $\mathrm{N}^{+}$; Amersham Pharmacia Biotech, Piscataway, $\mathrm{NJ}, \mathrm{USA}$ ) at $4^{\circ} \mathrm{C}$ overnight at $20 \mathrm{~V}$ in $0.25 \times$ TBE buffer. DNA was immobilized on the membranes by baking the blots at $80^{\circ} \mathrm{C}$ in a vacuum oven for 1 $\mathrm{h}$ and then exposing them to UV irradiation for 1 min using a UV-transilluminator (UVP, San Gabriel, CA, USA).

Detection of biotin-labeled DNA was performed according to the Southern-Light ${ }^{\mathrm{TM}}$ protocol (Tropix, Bedford, MA, USA) at room temperature. The blots were washed $2 \times 5 \mathrm{~min}$ in the blocking buffer $\left(0.5 \mathrm{~mL} / \mathrm{cm}^{2}\right)$ consisting of $0.2 \% \mathrm{I}^{-B l o c k} \mathrm{TM}^{\mathrm{TM}}$ reagent (Tropix), $0.5 \%$ SDS and $1 \times \mathrm{MBS}(0.01 \mathrm{M}$ MOPS, 0.15 M NaCl, 0.005 M NaOH) and incubated further in the blocking buffer $\left(1 \mathrm{~mL} / \mathrm{cm}^{2}\right)$ for $10 \mathrm{~min}$. Alkaline phosphatase-conjugated streptavidin in buffered $50 \%$ glycerol (Avid $\mathrm{X}-\mathrm{AP}^{\mathrm{TM}}$; Tropix) was diluted 1:5000 in the blocking buffer. The blots were incubated for 20 min with constant agitation in the diluted avidin-alkaline phosphatase conjugate solution $(0.2 \mathrm{~mL} /$ $\mathrm{cm}^{2}$ ), followed by $1 \times 5 \mathrm{~min}$ wash in the blocking buffer and $3 \times 5$ min wash in the wash buffer $\left(1 \mathrm{~mL} / \mathrm{cm}^{2}\right)$ consisting of $1 \times \mathrm{MBS}$ and $0.5 \%$ SDS. After 2 $\times 2$ min wash in $20 \mathrm{mM}$ Tris- $\mathrm{HCl}(\mathrm{pH}$ 9.8) containing $1 \mathrm{mM} \mathrm{MgCl}_{2}$, the blots were briefly drained and placed on Saran ${ }^{\circledR}$ wrap. A thin layer of CSPDready-to-use-substrate solution (Tropix) was pipetted onto the blots (3 $\mathrm{mL} / 100 \mathrm{~cm}^{2}$ ) and incubated for $5 \mathrm{~min}$. After removal of the excess CSPD solution, the blots were placed into development folders $\left(14 \times 19 \mathrm{~cm}^{2}\right.$ clear polypropylene sheets; Tropix) and exposed to X-Omat ${ }^{\mathrm{TM}}$-AR film (Eastman Kodak, Rochester, NY, USA) for 5-10 min. Signals on X-ray film were captured by a Model 4910 high-performance charge-coupled device (CCD) camera (COHU, San Diego, CA, USA. The captured images were analyzed by NIH Image version 1.55 software.

\section{Northern Blot Analysis}

Expression of TrkB was examined by Northern hybridization using the 3.9 
kbp TrkB cDNA clone as a probe (7). Twenty micrograms of each RNA preparation were subjected to Northern blot analysis as previously described (10). The blot was washed in $0.1 \times$ standard saline citrate containing $1 \%$ SDS at $63^{\circ} \mathrm{C}$ and was exposed to X-ray film at $-70^{\circ} \mathrm{C}$ overnight.

\section{RESULTS AND DISCUSSION}

The quantitative measurement of Trk family gene transcripts expressed in neuroblastoma cell lines and tumor specimens has traditionally been performed by Northern blot analysis using ACTIN or GAPD transcripts as invariant controls $(5,12)$. Northern blot analysis requires at least $10 \mu \mathrm{g}$ of total cellular RNA per sample, but there are times when available amounts of tumor RNA are limited. We therefore developed a duplex quantitative RT-PCR that requires only $1-2.5 \mu \mathrm{g}$ RNA per sample. In our protocol, TrkB and GAPD (i.e., an internal control) sequences were amplified together in the same PCR. To accurately determine the normalized expression of $T r k B$ (i.e., the ratio between $\operatorname{TrkB}$ and $G A P D$ expression), PCR was performed in the exponential phase of amplification for both $\operatorname{TrkB}$ and GAPD sequences. To detect the small amounts of PCR products generated, PCR primers were biotin-labeled at their $5^{\prime}$ ends, and the biotinylated PCR products were detected by an alkaline phosphatase-based chemiluminescence assay.

We found that the use of uniformly biotinylated $G A P D$ primers in the duplex relative quantitative PCR produced much stronger GAPD signals on $\mathrm{X}$-ray film as compared to those generated by $\operatorname{TrkB}$. This effect was due to relatively high levels of GAPD transcripts expressed in the cell, which caused inaccurate determination of the TrkB/ $G A P D$ ratio. To circumvent this problem, we made a simple modification to this protocol to reduce $G A P D$ signals detected on X-ray film without compromising the principle of relative quantitative PCR.

In the modified protocol, only a fraction of the GAPD primers used was biotinylated, while the rest were nonlabeled. The overall concentration of
$G A P D$ primers in the PCR remained the same. We defined a mixture of 5 -labeled and nonlabeled primers of the same sequence and concentration as the composite primers. The use of composite $G A P D$ primers made it possible for PCR amplification of both $\operatorname{Trk} B$ and $G A P D$ sequences to be performed in primer excess conditions. Lowering $G A P D$ primer concentrations to obtain less intensive signals was not desirable because the amplification kinetics of $G A P D$ became completely different from that of the $T r k B$ sequence (data not shown).

We first investigated the effect of partly biotinylated GAPD primers in relative quantitative RT-PCR. The expression of $\operatorname{TrkB}$ transcripts in the neuroblastoma cell line SMS-KCNR was examined using four different compositions of GAPD primers (Figure 1). TrkB and $G A P D$ sequences were amplified individually or together to compare the influence of different GAPD primer compositions on the amplification of a $\operatorname{TrkB}$ sequence (Figure 1). PCR was also carried out for 5, 10, 15 and 20 cycles to determine the optimal number of PCR cycles (Figure 1). Figure 1 shows that RT-PCR products were detected at the expected size both for the GAPD (160 bp) and the TrkB (247 bp). When $100 \%$ biotinylated primers were used, $G A P D$ generated strong signals that overexposed X-ray film (GAPD 1, Figure $1 \mathrm{~A})$. GAPD signals were decreased proportionally as the amount of biotinlabeled primers was reduced in the total $G A P D$ primers. We found that the composition of GAPD 1:49 (2\% biotinylated $+98 \%$ nonbiotinylated primers) was optimal because the signal intensities of both $\operatorname{TrkB}$ and $G A P D$ were ap-

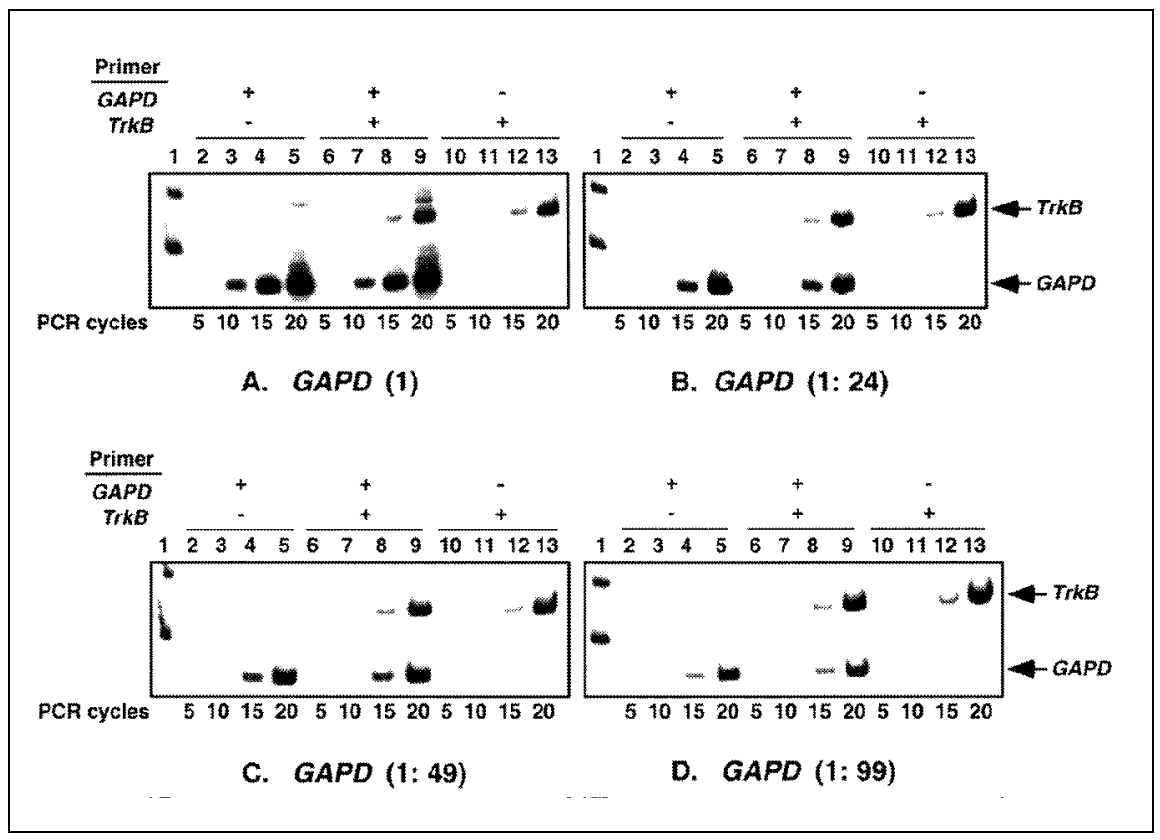

Figure 1. Co-amplification of $G A P D$ and $T r k B$ sequences using composite GAPD primers. Expression levels of co-amplified $G A P D$ and $T r k B$ sequences were compared with those of individually amplified $\operatorname{TrkB}$ and GAPD sequences. RT-PCR products of $\operatorname{TrkB}(247 \mathrm{bp})$ and $G A P D(160 \mathrm{bp})$ from the SMSKCNR cell line after 5, 10, 15 and 20 cycles of PCR were analyzed on 6\% polyacrylamide gels, followed by chemiluminescent detection. Four different compositions of the GAPD primers were used: (A) GAPD primers 1 (100\% biotinylated); (B) GAPD primers 1:24 (4\% biotinylated); (C) GAPD primers 1:49 (2\% biotinylated) and (D) GAPD primers 1:99 (1\% biotinylated). All four blots (A-D) were analyzed under the same conditions to minimize variations in transfer and detection. The PCR products were electrotransferred onto nylon membrane at the same time. DNA bands were detected simultaneously using the chemiluminescence procedure (see Materials and Methods), and the four blots were exposed simultaneouly to the same X-ray film. Lane 1: molecular weight marker (biotinylated, 50-1000 bp); lanes 2-5: GAPD amplified individually; lanes 6-9: GAPD and TrkB amplified together; lanes 10-13: TrkB amplified individually. GAPD signals decrease proportionally to the composition of the biotin-labeled primers included in the total GAPD primers. TrkB signals show a similar intensity in all four GAPD primer compositions used. Minor bands appeared at the position slightly larger than the TrkB signal in panel A at 20 cycles are likely due to the signal of unprocessed GAPD transcripts. 
proximately the same (Figure $1 \mathrm{C}$ ). In addition, 20 PCR cycles were found to be optimal (lanes 9 and 13 of Figure 1, A-D). Furthermore, it was found that the intensity of $\operatorname{Trk} B$ signals was not affected by the co-amplification of GAPD. Similar levels of TrkB signal were observed when the $\operatorname{Trk} B$ sequence was individually amplified (Figure 1, A-D, lanes 12 and 13) or when the TrkB sequence was co-amplified with different compositions of GAPD primers (Figure 1, A-D, lanes 8 and 9).

Figure 2 shows the $T r k B$ signals after 10,15 and 20 PCR cycles of amplification using the four different compositions of biotinylated GAPD primers (columns in gray). These data were compared to those amplified in the absence of the internal control GAPD (columns in black). As shown in Figure 2 , there was no significant difference between signals from both groups. The maximal variation of $\operatorname{Trk} B$ amplified individually was $14 \%$, while the maximal variation of $\operatorname{TrkB}$ co-amplified with four different compositions of biotinlabeled GAPD primers was $10 \%$. These data collectively indicate that the levels of $\operatorname{TrkB}$ expression determined were not affected by the composition of the $G A P D$ primers used.
To further examine the validity of this RT-PCR protocol for quantitative analysis, we analyzed the ratio between $T r k B$ and GAPD signals when four different compositions of GAPD primers were used. Figure 3 shows that when the composite GAPD primers (1\%, $2 \%$ and $4 \%$ biotinylated primers in the total $G A P D$ primers) were used, there was a linear relationship between the TrkB/ $G A P D$ signal ratio and the proportion of biotinylated GAPD primers. In contrast, when $100 \%$ biotinylated GAPD primers were used, the TrkB/GAPD ratio was out of the linear plot, which indicates that the GAPD signal that was detected exceeded the linear range of $\mathrm{X}$-ray film detection. The data also indicated that there was no preferential usage of either biotinylated or nonlabeled GAPD primers in the PCR. Taken together, the ratio between the $\operatorname{Trk} B$ and the GAPD signal can represent the relative level of $\operatorname{Trk} B$ expression.

We also confirmed that PCR was in the exponential phase of amplification both for GAPD and TrkB sequences at PCR cycles used for quantitative analysis (20 cycles). The TrkB sequence was amplified together with the GAPD sequence using the GAPD primer composition of 1:49 (2\% biotinylated) at dif-

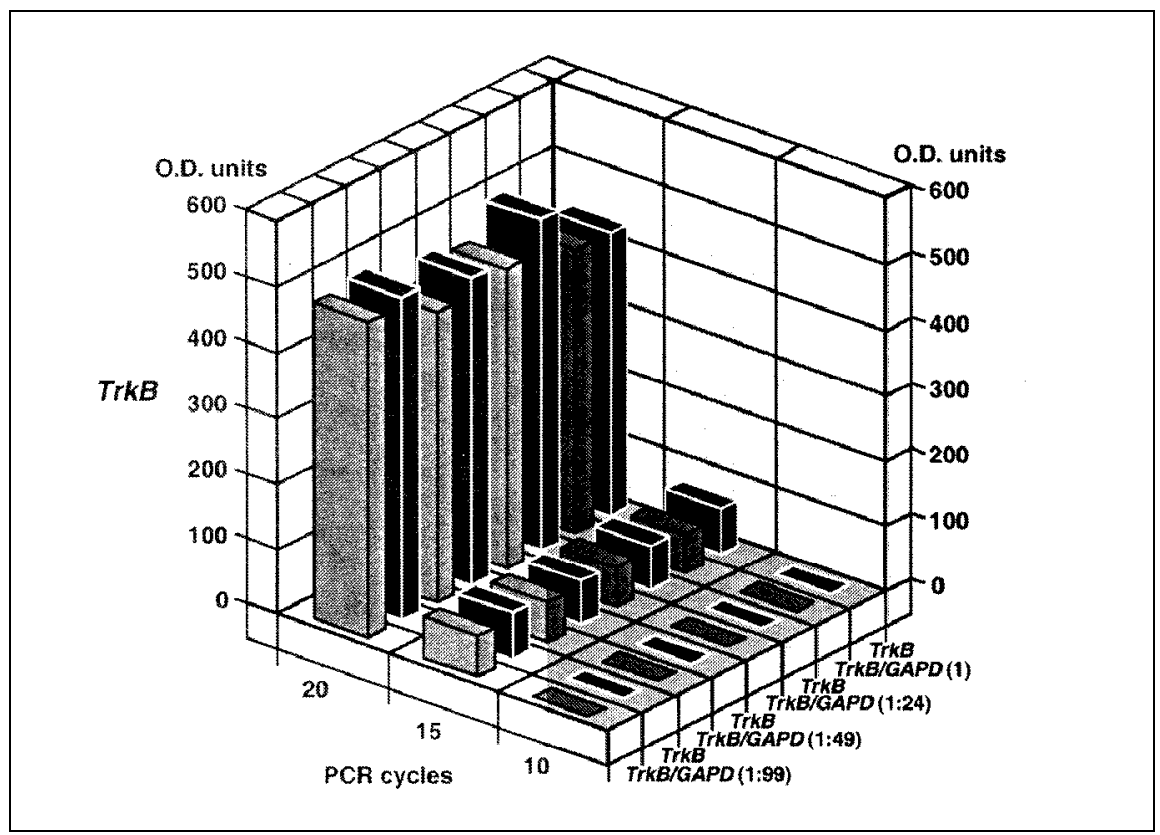

Figure 2. TrkB signals under various PCR conditions using TrkB primers alone or with different compositions of GAPD primers. Gray columns show TrkB signals after 10, 15 and 20 PCR cycles of PCR amplification using four different compositions of biotinylated GAPD primers. These data were compared to those amplified in the absence of the internal control GAPD (black columns). 


\section{Short Technical Reports}

ferent PCR cycles. The OD units of $G A P D$ and $T r k B$ were then plotted against PCR cycles (Figure 4 ). Figure 4 shows that PCR was in the exponential phase of amplification for both GAPD

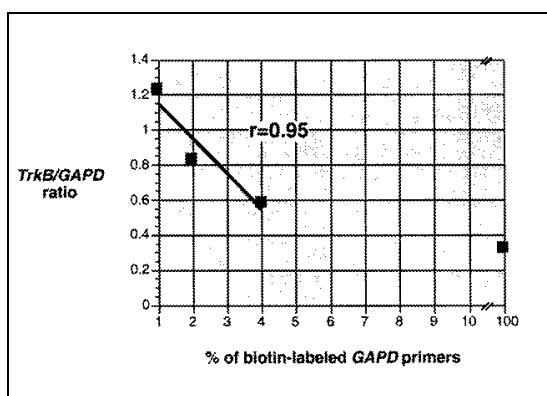

Figure 3. Relationship between the TrkB/ $G A P D$ ratio and the proportion of biotinylated primers in the total $G A P D$ primers. Relative quantitative RT-PCR analysis was performed using 20 PCR cycles. The ratio between TrkB and $G A P D$ signals was plotted against the proportion of biotin-labeled primers in the total GAPD primers. The linear regression analysis shows that the two parameters have a linear relationship $(\mathrm{r}=$ 0.95 ) when the composite GAPD primers were used $(1 \%, 2 \%$ and $4 \%)$.

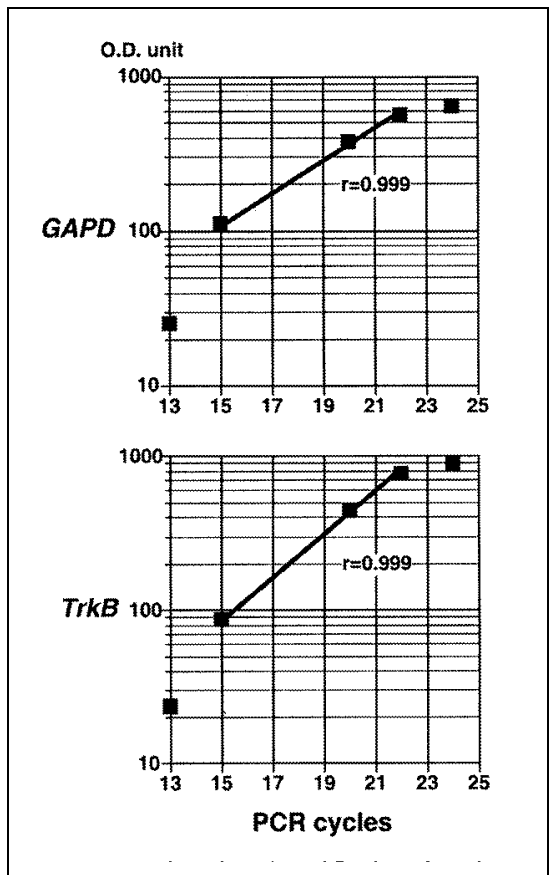

Figure 4. PCR amplification kinetics of TrkB and GAPD. TrkB and GAPD sequences were coamplified at the PCR cycles indicated. The composition of GAPD used was 1:49 (biotin-labeled:nonlabeled). Signal intensities of GAPD and $\operatorname{TrkB}$ were plotted against PCR cycles used, and the regression analysis was then performed. The results showed that both GAPD and TrkB sequences were amplified exponentially between 15 and 22 cycles of PCR. and TrkB between 15 and 22 cycles.

Finally, we examined whether the results of our PCR-based assay for quantitative transcript analysis were consistent with those of Northern blot analysis (Figure 5). RNA samples from three neuroblastoma cell lines (SMSKCNR, NBL-S and NLF) were first analyzed by Northern blot analysis. As shown in Figure 5, both full-length and truncated forms of $\operatorname{TrkB}(9 \mathrm{~kb}$ and 8.5 $\mathrm{kb}$, respectively) were detected in SMS-KCNR, but not in NBL-S or NLF by Northern blot analysis. Similarly, the results of the RT-PCR showed highlevel expression of TrkB in SMSKCNR, very low-level expression in NBL-S and no expression in NLF. Un-

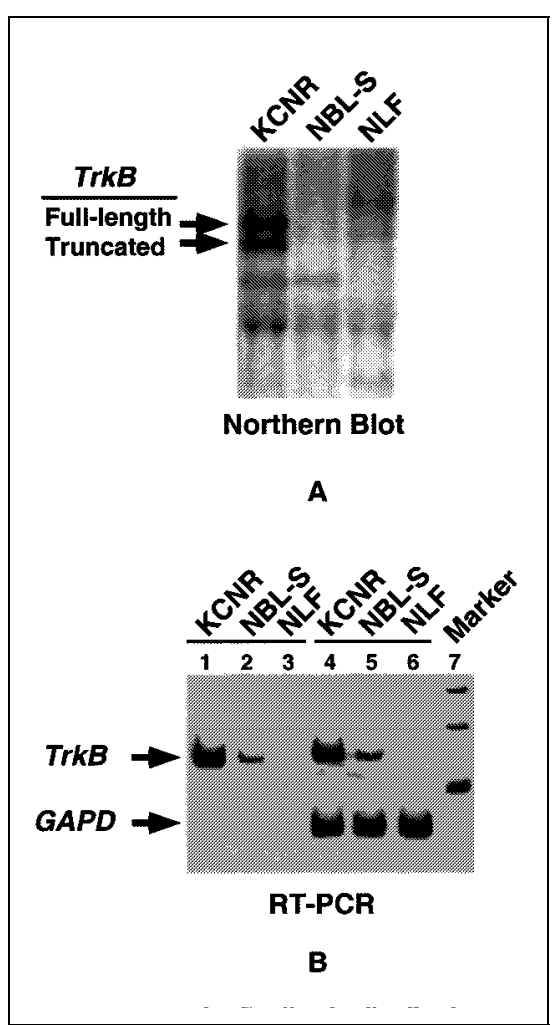

Figure 5. Comparison of the RT-PCR procedure with Northern blot analysis for TrkB expression in neuroblastoma cell lines. (A) Northern blot analysis was performed on total RNA samples of SMS-KCNR, NLF and NBL-S neuroblastoma cell lines. A full-length cDNA clone of human $\operatorname{TrkB}$ was used as a probe, which detected transcripts encoding full-length $(9 \mathrm{~kb})$ and truncated $(8.5 \mathrm{~kb})$ forms of $\operatorname{TrkB}$. (B) RT-PCR analysis was performed to examine the expression of $\operatorname{TrkB}$ transcripts in the same set of cell lines, using $\operatorname{Trk} B$ primers alone (lanes 1-3) or $T r k B$ and GAPD primers together (lanes 4-6). The composition of GAPD used was 1:49 (biotinlabeled:nonlabeled). der the experimental conditions used, the RT-PCR method was more sensitive than the Northern blot technique and thus was able to detect very low levels of $\operatorname{TrkB}$ expression in NBL-S. It should be mentioned that the TrkB primers used in the RT-PCR experiments were specific for the full-length form, and the truncated form of $\operatorname{Trk} B$ was not detected. Taken together, the data by these two methods were consistent. We confirmed this by examining the expression of TrkA and MYCN in a cohort of neuroblastoma tumor specimens by our method and comparing our data with the results previously generated by Northern blot (6) (Tang and Ikegaki, unpublished data).

In summary, we describe here a method for relative quantitative analysis of RNA transcript expression using the RT-PCR technique. The relative quantitative RT-PCR assay described met two important criteria. First, PCR was in the exponential phase of amplification for both the internal control and sequence of interest. Second, signal intensities of the internal control and sequence of interest were within the linear range of X-ray film detection. This was achieved by the use of composite primers for the internal control. These features ensured accurate determination of the normalized expression of transcripts of interest. The protocol is simple to set and requires no major equipment to perform and so would be useful for relative quantification of transcript levels expressed in cells and tissues. Furthermore, the use of composite primers may have a wide range of applicability to quantitative nucleic acid analyses.

\section{REFERENCES}

1.Chelly, J., J.C. Kaplan, P. Maire, S. Gautron and A. Kahn. 1988. Transcription of the dystrophin gene in human muscle and non-muscle tissue. Nature 333:858-860.

2.Gilliland, G., S. Perrin, K. Blanchard and H.F. Bunn. 1990. Analysis of cytokine mRNA and DNA: detection and quantitation by competitive polymerase chain reaction. Proc. Natl. Acad. Sci. USA 87:2725-2729.

3.Horikoshi, T., K.D. Danenberg, T.H. Stadlbauer, M. Volkenandt, L.C. Shea, K. Aigner, B. Gustavsson, L. Leichman et al. 1992. Quantitation of thymidylate synthase, dihydrofolate reductase, and DT- diaphorase gene expression in human tumors using the poly- 
merase chain reaction. Cancer Res. 52:108116.

4.Martin, C.S., L. Butler and I. Bronstein. 1995. Quantitation of PCR products with chemiluminescence. BioTechniques 18:908913.

5.Nakagawara, A., M. Arima, C.G. Azar, N.J. Scavarda and G.M. Brodeur. 1992. Inverse relationship between trk expression and $\mathrm{N}$ myc amplification in human neuroblastomas. Cancer Res. 52:1364-1368.

6.Nakagawara, A., M. Arima-Nakagawara, N.J. Scavarda, C.G. Azar, A.B. Cantor and G.M. Brodeur. 1993. Association between high levels of expression of the TRK gene and favorable outcome in human neuroblastoma. N. Engl. J. Med. 328:847-854.

7.Nakagawara, A., X.G. Liu, N. Ikegaki, P.S. White, D.J. Yamashiro, L.M. Nycum, J.A. Biegel and G.M. Brodeur. 1995. Cloning and chromosomal localization of the human $T R K-B$ tyrosine kinase receptor gene (NTRK2). Genomics 25:538-546.

8.Rappolee, D.A., D. Mark, M.J. Banda and Z. Werb. 1988. Wound macrophages express TGF-alpha and other growth factors in vivo: analysis by mRNA phenotyping. Science 241:708-712.
9.Svensson, T., M. Ryden, F.H. Schilling, C. Dominici, R. Sehgal, C.F. Ibanez and P. Kogner. 1997. Coexpression of mRNA for the full-length neurotrophin receptor trk-C and trk-A in favourable neuroblastoma. Eur. J. Cancer 33:2058-2063.

10.Tang, X.X., J.A. Biegel, L.M. Nycum, A. Yoshioka, G.M. Brodeur, D.E. Pleasure and N. Ikegaki. 1995. cDNA cloning, molecular characterization, and chromosomal localization of NET(EPHT2), a human EPH-related receptor protein-tyrosine kinase gene preferentially expressed in brain. Genomics 29:426437.

11.Wang, A.M., M.V. Doyle and D.F. Mark. 1989. Quantitation of mRNA by the polymerase chain reaction. Proc. Natl. Acad. Sci. USA 86:9717-9721.

12.Yamashiro, D.J., X.G. Liu, C.P. Lee, A. Nakagawara, N. Ikegaki, L.M. McGregor, S.B. Baylin and G.M. Brodeur. 1997. Expression and function of Trk-C in favourable human neuroblastomas. Eur. J. Cancer 33:2054-2057.

13.Yamashiro, D.J., A. Nakagawara, N. Ikegaki, X.G. Liu and G.M. Brodeur. 1996. Expression of TrkC in favorable human neuroblastomas. Oncogene 12:37-41.
This work was supported in part by National Institutes of Health Grant Nos. CA70958 (to N.I.) and NS34514 (to G.M.B.), and by the Deutsche Krebshilfe/ Dr. Milred Scheel-Stifung (to A.E.). Address correspondence to Dr. Naohiko Ikegaki, Division of Oncology, Children's Hospital of Philadelphia, Abramson Research Center Room 902, 3516 Civic Center Blvd., Philadelphia, PA 19104-4318, USA. Internet: ikegaki@email.chop.edu

Received 17 May 1999; accepted 7 January 2000.

\section{Angelika Eggert, Garrett M. Brodeur and Naohiko Ikegaki Children's Hospital of Philadelphia Philadelphia, PA, USA}

